\title{
Ventricular tachycardia after administration of sildenafil citrate: a
} case report Jeppe G Rasmussen*1, Egon Toft ${ }^{1,2}$ and Ole Frøbert ${ }^{1,3}$

Address: ${ }^{1}$ Department of Cardiology, Center for Cardiovascular Research, Aalborg Hospital, Aarhus University Hospital, Hobrovej 18-22, 9000 Aalborg, Denmark, ${ }^{2}$ Department of Health Science and Technology, Center for Sensory-Motor Interaction, University of Aalborg, Fredrik Bajers Vej 7 D3, 9220 Aalborg, Denmark and ${ }^{3}$ Department of Pharmacology, University of Aarhus, Bartholin Bygningen, 8000 Aarhus, Denmark

Email: Jeppe G Rasmussen* - jgr1@dadlnet.dk; Egon Toft - egt@rn.dk; Ole Frøbert - frobert@dadlnet.dk

* Corresponding author

Published: 13 August 2007

Journal of Medical Case Reports 2007, I:65 doi:10.1 186/1752-1947-I-65
Received: 27 February 2007

Accepted: 13 August 2007

This article is available from: http://www.jmedicalcasereports.com/content/I/I/65

(c) 2007 Rasmussen et al; licensee BioMed Central Ltd.

This is an Open Access article distributed under the terms of the Creative Commons Attribution License (http://creativecommons.org/licenses/by/2.0), which permits unrestricted use, distribution, and reproduction in any medium, provided the original work is properly cited.

\begin{abstract}
Background: It has not previously been reported that sildenafil citrate causes malignant arrhythmias in humans.

Case presentation: A 4I-year-old man developed sustained ventricular tachycardia following sildenafil citrate administration.

Conclusion: It cannot be dismissed that this patient experienced ventricular tachycardia as an adverse effect of sildenafil citrate administration.
\end{abstract}

\section{Background}

Concerns about the safety of sildenafil citrate (Viagra $\left.{ }^{\circledast}\right)$ have previously been raised [1]. Other case reports and studies have described electrophysiological changes associated with ventricular arrhythmias following administration of sildenafil citrate [2-4].

We describe a case of a young man with no cardiac history or family history of heart disease or sudden death, developing sustained ventricular tachycardia after ingestion of sildenafil citrate. This case highlights a potential adverse effect of sildenafil citrate and the possible morbidity and potential lethality associated with this adverse effect.

\section{Case presentation}

In August, 2006, a 41-year-old man was transferred after an episode of sustained monomorphic ventricular tachycardia (VT). There was no history of any cardiopulmonary symptoms and no family history of heart disease or sudden death. The arrhythmia started after 90 minutes of moderate pace swimming. In the locker room the patient felt dizzy, had a feeling of tachycardia and experienced a brief, witnessed syncope. At admission to the referring hospital VT with a frequency of $220 \mathrm{~min}^{-1}$ was documented (figure 1). Blood pressure was $105 / 60 \mathrm{mmHg}$. Before transferral, the VT was treated with metoprolol 2 milligrams and amiodarone 300 milligrams intravenously and converted to sinus rhythm.

Approximately 10 hours prior to the arrhythmia the patient had taken sildenafil citrate $\left(\right.$ Viagra $\left.^{\circledR}\right) 100 \mathrm{mg}$ orally, which had been prescribed because of erectile dysfunction. He was not taking any other medication. Blood tests were unremarkable except for troponin $\mathrm{T}(0.82$ mikrograms/Liter) and CKMB (40.8 mikrograms/Liter). Resting ECG, bicycle ergometer exercise testing, echocardiography with tissue Doppler imaging, coronary angiography and cardiac nuclear magnetic resonance scanning were all normal. Six endomyocardial biopsies from the right ventricle showed slight non-specific hypertrophy 


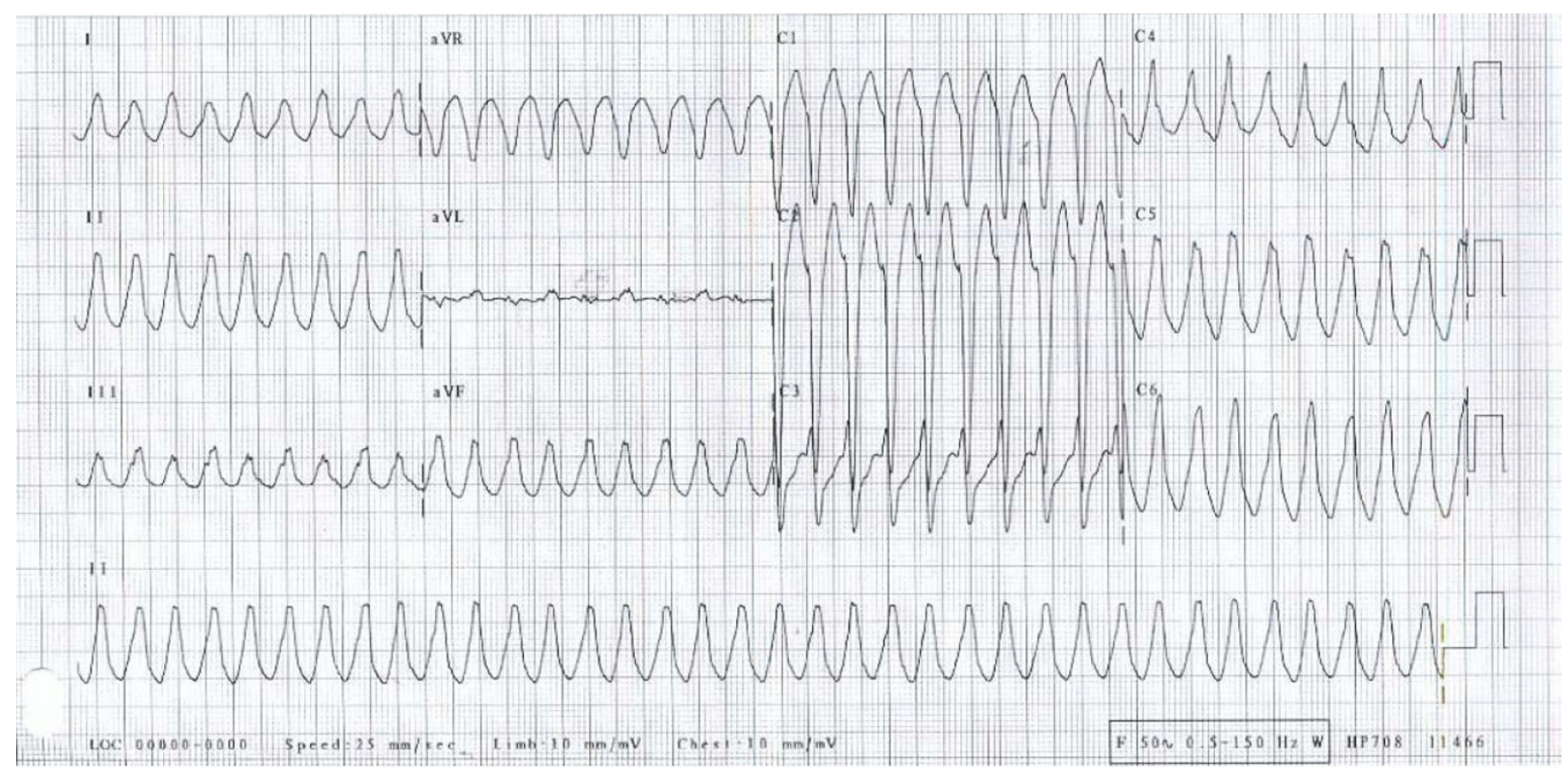

Figure I

Sustained ventricular tachycardia in a $4 \mathrm{I}$-year-old man receiving sildenafil therapy. Original tracing when the patient was admitted to the hospital.

and slight interstitial fibrosis and no suspicion of arrhythmogenic right ventricle cardiomyopathy. An electrophysiological study using protocol stimulation in the apex and the outflow tract of the right ventricle induced 10 beats of non-sustained VT with alternating morphology. On a subsequent day, an additional electrophysiological study was conducted 41/2 hours following administration of 100 mg of Viagra ${ }^{\circledR}$ orally (serum concentration $0.36 \mathrm{mg} / \mathrm{kg}$ ). On that occasion a non-sustained VT over 24 beats identical to the VT at admission was induced (figure 2). A prophylactic implantable cardioverter defibrillator (ICD) was implanted and the patient was instructed not to use sildenafil. At a follow-up visit in December 2006 interrogation of the ICD revealed that two events of VT had been detected and terminated by anti tachycardia pacing.

\section{Discussion and conclusion}

Sildenafil citrate is widely used to treat male erectile dysfunction and therapeutic uses for other diseases such as pulmonary hypertension are emerging. Sildenafil citrate has proven to be safe when used in the treatment of erectile dysfunction of organic, psychogenic or mixed causes [5]. Concerns about the effects of phosphodiesterase-5 inhibitors on the heart and their safety in patients with cardiovascular disease have been raised. The concerns include effects on blood pressure, heart rate and cardiac electrophysiology. This led to the publishing of a report from the U.S. Food and Drug Administration, describing deaths in patients having been prescribed sildenafil citrate in the first period after the marketing from late March through mid-November 1998 [1]. In this period, >6 million outpatient prescriptions were dispensed. Of the 130 confirmed deaths among men (mean age, 64 years) who received sildenafil citrate, 77 had cardiovascular events, including 41 with myocardial infarction and 27 with cardiac arrest. Cause of death was unknown in 48 and noncardiac in 5 men. The time from drug ingestion to death or onset of symptoms leading to death was $<5$ hours for 44 men, later the same day; 6 men, the next day; 8 men, two to seven days later; 9 men and unknown for the remainder. Sildenafil citrate blocks the rapid component of the delayed rectifier potassium current in guinea pig hearts [2] and produces small but significant increases in the QTc interval in humans [3]. Sildenafil has been reported to cause VT in pigs when administered in combination with a nitric oxide donor [4].

We conclude that our patient had no confirmable cardiac condition other than VT. The hypothesis, that this patient, with documented episodes of non-sustained VT, experienced an episode of sustained VT caused by sildenafil citrate lowering the VT threshold, cannot be dismissed. 


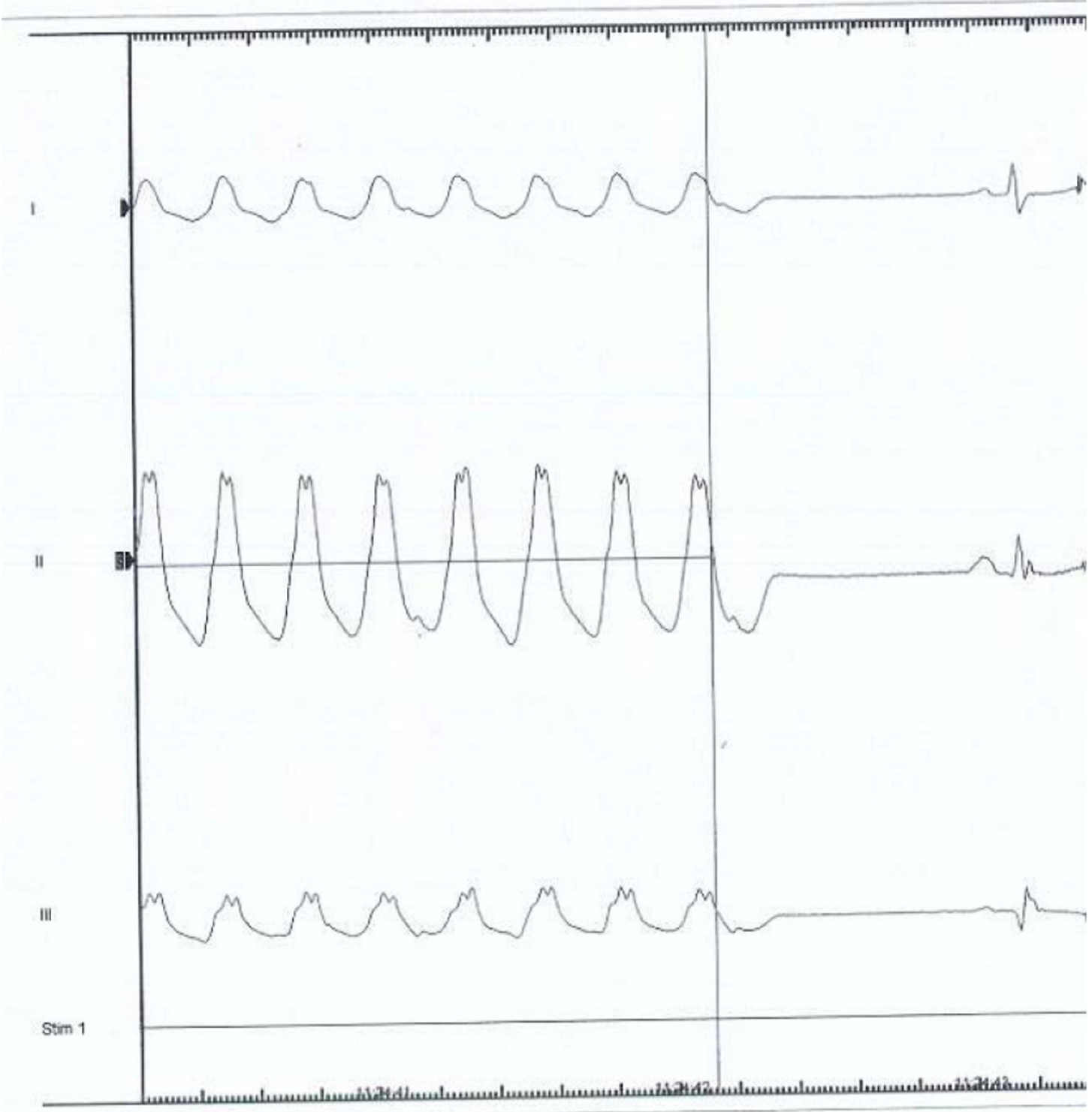

\section{Figure 2}

Ventricular tachycardia induced during electrophysiological study. The study was conducted $4 \mathrm{I} / 2$ hours following administration of $100 \mathrm{mg}$ of Viagra ${ }^{\circledR}$ orally. A non-sustained VT over 24 beats identical to the VT at admission was induced.

\section{Abbreviations}

1. VT: Ventricular tachycardia

2. ICD: Implantable cardioverter defibrillator

\section{Competing interests}

The author(s) declare that they have no competing interests.

\section{Authors' contributions}

All authors were involved in writing/reviewing the manuscript. All authors approved the final manuscript.

\section{Acknowledgements}

Full written consent has been obtained from the patient for submission of this manuscript for publication. Funding was neither sought nor obtained.

\section{References}

I. Food and Drug Administration: Postmarketing safety of sildenafil citrate (Viagra). Summary of reports of death in Viagra users received from marketing (late March) through midNovember 1998. [http://www.fda.gov/cder/consumerinfo/viagra/ safety3.htm].

2. Geelen P, Drolet B, Rail J, Bérubé J, Daleau P, Rousseau G, Cardinal R, O'Hara GE, Turgeon J: Sildenafil (Viagra) Prolongs Cardiac Repolarization by Blocking the Rapid Component of the Delayed Rectifier Potassium Current. Circulation 2000, 102:275-277. 
3. Ilson BE, Shaddinger BC, Dabiri GA, Patel BR, Boyle DA, Sethuraman $V$, Montague T, Morganroth J: A definitive study of the effects of PDE-5 inhibitors on cardiac repolarization in middle-age males. Journal of Clinical Pharmacology \& Therapeutics 2004, 75:47.

4. Swissa M, Ohara T, Lee MH, Kaul S, Shah PK, Hayashi H, Chen PS, Karagueuzian HS: Sildenafil-nitric oxide donor combination promotes ventricular tachyarrhythmias in the swine right ventricle. American Journal of Physiology-Heart and Circulatory Physiology 2002, 282(5):HI787-HI792.

5. Goldstein I, Lue TF, Padma-Nathan H, Rosen RC, Steers WD, Wicker PA: Oral Sildenafil in the treatment of erectile dysfunction. New England Journal of Medicine 1998, 338:1397-I 404.

Publish with Bio Med Central and every scientist can read your work free of charge

"BioMed Central will be the most significant development for disseminating the results of biomedical research in our lifetime. "

Sir Paul Nurse, Cancer Research UK

Your research papers will be:

- available free of charge to the entire biomedical community

- peer reviewed and published immediately upon acceptance

- cited in PubMed and archived on PubMed Central

- yours - you keep the copyright

Submit your manuscript here:

http://www.biomedcentral.com/info/publishing_adv.asp 